УДК: 94:327.8-029:39(438:47+57) «1944»

Володимир ЛУЩАЙ,

orcid.org/0000-0001-8629-8335 кандидат історичних наук,

доиент кафедри етнології та краєзнавства

Національного педагогічного університету

імені М.П. Драгоманова (Україна, Київ)

inagy@ukr.net,

Ірина БАТЮК,

orcid.org/0000-0003-2381-3269

магістр історії, лаборант кафедри етнологіі та краєзнавства Національного педагогічного університету імені М.П. Драгоманова (Украӥна, Київ)

irynabatiuk@ukr.net

\title{
ПОРАЗКА ВАРШАВСЬКОГО ПОВСТАННЯ 1944 Р. ЯК ПРОЯВ ТА НАСЛІДОК ЕТНОНАЦІОНАЛЬНОГО ЧИННИКА НАЦІОНАЛЬНОЇ ПОЛІТИКИ РАДЯНСЬКОГО КОМУНІСТИЧНОГО РЕЖИМУ
}

У статті розглядається проблема Варшавського повстання 1944 р. в контексті виявлення ключової причини ї̈ поразки. Воєнно-політичними передумовами повстання було потрапляння Польщі влітку 1944 р. у сферу політичного впливу Радянського Союзу внаслідок розгрому групи армій «Центр» радянською армією (РА), а також утворення 21 липня 1944 р. у Москві ПКНВ на противагу уряду в еміграції С. Миколайчика. Аналіз воєнних передумов Варшавського повстання 1944 р., врахування очевидної переваги РА у силах $і$ засобах, ситуачії всередині німецького вищого військового командування після замаху на А. Гітлера в липні 1944 р. та становища німеиьких військ на варшавському напрямку, наявності південних плацдармів на західному березі Вісли та кількадесят тисяч бійців Армії Крайової (АК) у Варшавській окрузі формують висновок, що на початку серпня РА була здатна у короткостроковій перспективі звільнити Варшаву. Проте в ніч на 1 серпня наступ РА було призупинено до 9 вересня, в чому ми вбачаємо політичну мотивацію Кремля через задуми про комуністичне майбутнє Польщі. Внаслідок відсутності допомоги з боку РА, неможливості дієвої допомоги з боку союзницьких сил через політику Кремля, значної переваги німечьких військ Варшавське повстання 1944 р. завершилося поразкою, яка стала одночасно проявом та наслідком етнонаціонального чинника національної політики радянського комуністичного режиму.

Ключові слова: Варшавське повстання 1944 р., воєнно-політичні передумови, національна політика, етнонаціональний чинник, Радянська армія, Армія Крайова.

Volodymyr LUSHCHAI, Candidate of Historical Sciences, Associate Professor of the Department of Ethnology and Local History of the National Pedagogical University named MP Drahomanov (Ukraine, Kyiv) inagy@ukr.net, Irina BATIUK,

orcid.org/0000-0003-2381-3269

Master of History, Laboratory of the Department of Ethnology and Local History of the National Pedagogical University named MP Drahomanov (Ukraine, Kyiv) irynabatiuk@ukr.net 


\title{
DEFEAT OF THE WARSAW UPRISING IN 1944 AS AN OSTENT
}

AND AFTEREFFECT OF AN ETHNONATIONAL FACTOR IN THE

\author{
NATIONAL POLICY OF THE SOVIET COMMUNIST REGIME
}

\begin{abstract}
The article deals with the problem of the Warsaw uprising of 1944, in the context of identifying the key cause of its defeat. The main idea of the article is the thesis that the key cause of the defeat of the Warsaw uprising of 1944 was the ethno-national factor of the national policy of the Soviet communist regime, which was manifested in the specific bias and politically motivated attitude of the regime to the Poles as an nation, their aspirations for freedom and state-building.

It was found that the key military-political preconditions of the Warsaw Uprising was the appearance of Poland in the sphere of action of the Soviet Army (SA) in summer 1944 and political influence of the Soviet Union as a result of the defeat of the "Center" Army Group and the exit of SA to the territory of Poland, the formation on July 21, 1944 of the Polish Committee for National Liberation (Lublin Committee) in Moscow against the government of Mikotajczyk.

Analysis of the military preconditions of the Warsaw Uprising of 1944, taking into account the apparent advantage of the SA in the forces and means after the defeat of the "Center" Army Group, the presence of southern bridgeheads on the west bank of the Vistula, the situation inside the German higher military command after the attempt on Hitler's life on July 20, 1944. and the condition of the German troops in the direction of Warsaw at the end of July, several hundred soldiers of the Home Army (Armia Krajowa, AK) available in the Warsaw district, forms the conclusion that in early August, SA was capable of short-term liberation of Warsaw from the Germans.

However, on the night of August 1, the attack of the SA was suspended until September 9, in what, in view of the above-mentioned military-political preconditions of the uprising, the political motivation of the Kremlin is seen through the plans for the communist future of Poland. What is a vivid manifestation of the ethnonational factor of the national policy of the Soviet communist regime.

However, due to the lack of assistance from the SA prior to the onset of its offensive on September 9 , 1944, the impossibility of effective assistance from the Allied forces through the Kremlin's policy, a significant advantage of the German troops, the Warsaw uprising of 1944 ended in defeat that became simultaneously a ostent and aftereffect of the ethno-national factor in the national policy of the Soviet communist regime.

Key words: the Warsaw uprising of 1944, military-political preconditions, national politics, the ethnonational factor, the Soviet Army, the Home Army.
\end{abstract}

Постановка проблеми. Людська пам'ять коротка. 3 одного боку це добре, бо таким чином люди захищають себе від небажаних спогадів, а 3 іншого - звісно ж ні, бо так з часом розчиняються події, на основі аналізу яких можна дійти до більш глибоких і виважених висновків про минуле, навіть через десятиліття чи століття. На щастя, історія виконує роль стійкої пам'яті, яка здатна не лише зберегти для нас так званий фактаж, а й, через відтворення подій на основі аналізу усіх аспектів досліджуваної проблеми, пов'язати певну історичну подію 3 іншими, можливо на перший погляд лише дотичними або й загалом не важливими відносно конкретного дослідження подіями, синхронізувати іiі 3 різними внутрішніми та зовнішніми чинниками впливу, кореспондувати до дослідження конкретних подій окремі положення і висновки проблем, що перебувають 
за межами предмету дослідження. I використовуючи історію як науку у вищезазначеному ключі, ми здатні всебічно, об'єктивно і не заангажовано проаналізувати будь які історичні події та виявити причини першочергового і другорядного впливу, що ми й спробуємо здійснити на цілком доступному фактологічному та джерельному матеріалі проблеми Варшавського повстання $1944 \mathrm{p}$.

Сьогодні навіть у Польщі інколи лунають думки, що цілком узгоджуються 3 кремлівською ідеологемою радянських часів, про головну відповідальність еміграційного уряду С. Миколайчика та головнокомандувача Армії Крайової (АК) генерала Т. Коморовського (позивний «Бур») як першопричини настільки трагічних наслідків Варшавського повстання 1944 p. Проте ми, здійснивши попередньо конкретно історичне дослідження Варшавського повстання 1944 р. в контексті його передумов, причин та наслідків (Наукові праці історичного факультету Запорізького національного університету, № 50 (подано до друку)), застосувавши історико-аналітичний метод, метод реконструкції, опираючись на методологічні принципи багатофакторності, всебічності, системності та аксіологічного підходу, що передбачають з'ясування причин, умов виникнення та розвитку подій, визначення їх причиннонаслідкового зв'язку, вважаємо причиною першочергового впливу на настільки трагічну поразку повстання у Варшаві влітку-восени 1944 р. рішення вищого партійного керівництва КПРС в особі Й. Сталіна i політику СРСР щодо Польщі, зокрема, національну політику радянського комуністичного режиму та іiї етнонаціональний чинник.

В умовах загострення боротьби українського народу за незалежність i суверенітет на сучасному історичному етапі проблема поразки Варшавського повстання 1944 р. набуває особливої актуальності.

Аналіз досліджень. Повстання у Варшаві 1944 р. було предметом дослідження істориками минулого і сучасності. За радянської доби 
з'явилася низка робіт, що, в дусі радянських ідеологем, ігнорують реальні воєнні передумови та очевидні політичні мотиви зупинення радянського наступу на початку серпня 1944 р. Завуальовуючи дійсні причини зупинки радянського наступу, їх автори описують танкові бої 3-го танкового корпусу 2-ї танкової армії з трьома німецькими танковими дивізіями, забуваючи про інші військові з'єднання 2-ї танкової армії, уникають аналізу дій інших радянських армій на варшавському напрямку (Алтунин, 1884; История, 1978; Назаревич 1989; Штеменко, 1968). Подібну «спадковість» в оцінках і упередженості переважно демонструють сучасні російські дослідники, які ігнорують реальні воєнні передумови повстання, аналізуючи за радянським шаблоном дії 2-ї танкової армії та інших армій на варшавському напрямку, виривають окремі події 3 загального контексту, не враховують оперативної обстановки у Варшаві напередодні повстання, ігнорують очевидні політичні мотиви зупинення радянського наступу на початку серпня 1944 р. тощо (Мельтюхов, 2004; Польша в XX веве, 2012). Польська історіографія більш об’єктивно оцінює трагічні події у Варшаві, їх передумови і причини (Gdański, 2005; Motyka et al, 2012; Tebinka, 2004; Дильонгова, 2007). Хоча, польські історики, висвітлюючи політичну мотивацію Кремля в ухваленні рішення про призупинення наступу Радянської армії (РА) через задуми про комуністичне майбутнє Польщі та усунення політичної конкуренції шляхом знищення АК руками німців, не вбачають у цьому прояву національної політики радянського комуністичного режиму щодо польського народу. Розробку комплексу проблем Варшавського повстання 1944 р. в українській історіографії загалом можна охарактеризувати як вкрай недостатню, зорієнтовану на описі перебігу самого повстання (Скорич, 2016; Мельник; Ісаюк; Лук'янюк; Ісаєв), без приділення належної уваги його воєнно-політичним передумовам, глибокому аналізу зовнішньополітичних чинників подій в 
контексті становлення двополюсного світопорядку та геополітичних факторів, виявлення ключових причин його поразки.

Мета статті. Зважаючи на стан дослідження комплексу проблем Варшавського повстання 1944 р. метою даної статті є глибокий аналіз воєнно-політичних передумов повстання у Варшаві 1944 р. та виявлення фундаментальних причин його настільки масштабної поразки. Дослідження $є$ частиною держбюджетної науково-дослідної теми «Етнонаціональний чинник національної політики радянського комуністичного режиму щодо українського та польського народів (1920 1940 pp.)».

Виклад основного матеріалу. Для об’єктивного дослідження Варшавського повстання 1944 р. та підтвердження тези про ключову причину його настільки катастрофічної й трагічної поразки слід докладно проаналізувати воєнно-політичні передумови повстання. Після висадки союзників у Нормандії на початку червня 1944 р. РА отримала можливість для широкомасштабного наступу в Білорусії, що завершився розгромом групи армій «Центр» і виходом до території Польщі. Під час участі РА у бойових діях на території Польщі 21 липня 1944 р. у Москві представники лівих польських партій у складі промосковської Крайової Ради Народової, на противагу визнаному західними союзниками й діючому з 1939 р. у Лондоні уряду Польщі у вигнанні, якому підпорядковувалась більша частина антинімецького спротиву, включаючи АК, утворили другий польський осередок влади - Польський комітет національного визволення (ПКНВ). ПКНВ проголосив себе тимчасовим урядом Польщі і отримав визнання Радянського Союзу, який зобов'язався передати ПКНВ владу на звільнених від Німеччини польських територіях (Лук'янюк; Дильонгова, 2007: 154). Відносини з урядом в еміграції були розірвані за ініціативою радянської сторони ще 25 квітня 1943 р. як відповідь на реакцію польського уряду на німецьку заяву про розстріли радянським режимом 
польських офіцерів восени 1940 р. поблизу Смоленська (Tebinka, 2004: 139). Таким чином, влітку 1944 р. Польща не лише у форматі геополітичних реалій, вірогідних негласних домовленостей між лідерами Великої Британії, США та СРСР, а й фактично стала не просто частиною оперативної сфери дій радянських військ, а й сфери політичного впливу i відповідальності Радянського Союзу.

Польща була стратегічно важливою як з військово-політичної, так і 3 ідеологічної точки зору. Варшава являла собою важливий стратегічний укріплений район, втрата якого німцями відкривала РА шлях в центральну Європу, на Берлін та у Східну Пруссію. Незважаючи на те, що у радянській науковій літературі часто оперують політично вмотивованими фразами на кшталт таких, що Варшава не розглядалася в якості орієнтира для дій радянських військ, аналіз планів радянського командування свідчить про протилежне. Значною мірою, через необхідність створити передумови для «звільнення» Польщі та ії столиці, звісно, не виключаючи й Східної Пруссії та Прибалтики, на центральній ділянці радянськонімецького фронту і було сплановано та проведено силами чотирьох фронтів операцію «Багратіон», здійснення якої вважалося ключовим завданням радянських військ на літо 1944 р. (Штеменко, 1968: 286; Мельтюхов, 2004). Тут слід додати, що в історії воєн звільнення чи захоплення столиці завжди було одним з пріоритетів військових операцій, зважаючи на ідеолого-політичне та матеріально-ресурсне значення.

Важливою щодо всебічного дослідження воєнних передумов повстання є аналіз розстановки сил. Слід відзначити, що у складі 1-го Прибалтійського, 3, 2 і 1-го Білоруських фронтів було 27 армій, що включали 166 стрілецьких дивізій, 12 танкових і механізованих корпусів, та 21 бригаду. Німецька група армій «Центр», разом зі з’єднаннями сусідніх груп армій, могла протиставити 63 дивізії та 3 піхотні бригади, гарно розвинуту мережу залізничних i шосейних доріг. Загалом, 
співвідношення сил і засобів сторін на початок операції коливалося від 2:1 в особовому складі, 3,8:1 в гарматах і мінометах, 3,9:1 в бойових літаках, до 5,8:1 в танках і САУ на користь РА (История, 1978: 42-47).

Після розгрому групи армій «Центр» брестсько-люблінська операція 1-го Білоруського фронту передбачала вихід після звільнення Бреста (звільнено 28 липня) і Любліна (24 липня) широким фронтом до Вісли, захоплення плацдармів з півдня і півночі від Варшави і в передмісті польської столиці Празі (История, 1978: 55-56; Назаревич, 1989: 88). Директива Ставки Верховного Головнокомандування командуючому військами 1-го Білоруського фронту від 27 липня про наступ на варшавському напрямку передбачала після оволодіння районом Брест i Сєдльце правим крилом фронту розвивати наступ в загальному напрямку на Варшаву з завданням не пізніше 5-8 серпня оволодіти Прагою (Русский архив, 1994: 201). Очевидно, що саме з метою захоплення Варшави і мали створюватися плацдарми південніше, по центру і північніше польської столиці.

29 липня було захоплено південні плацдарми на Віслі південніше Пулав, протягом 28 липня - початку серпня - в районі Магнушев. В цьому районі була надзвичайна перевага у повітрі радянської авіації: в період з 18 по 31 липня силами лише однієї 6-ї повітряної армії було виконано 12 тис. літако-вильотів і німецька авіація після значних втрат в середині серпня припинила активні дії в цьому районі, де діяла також й 16-а повітряна армія (История, 1978: 60). Станом на 31 липня 47-а армія і 2-а танкова армія, за підтримки 11-го танкового та 2-го кавалерійського корпусів, захопили Седльце, розташоване близько 80 км південніше від Варшави. Тим часом, та сама 2-а танкова армія вздовж Вісли вийшла до варшавського передмістя Прага, звільнивши протягом 30 липня сусідні Отвоцк, Воломін і Радзімін, перебувала від столиці на відстані не більше 10 км. Слід додати до них і діючі на варшавській ділянці фронту 70-у, 28-у, 
65-у і 48-у армії, а також 1-у армію Війська Польського(ВП), що з 27 липня розташовувалася між пулавським і магнушевським плацдармами (История, 1978: 60-62; Назаревич, 1989: 88-89).

Натомість, німецькі війська ще наприкінці липня, під тиском РА, що лише наближалася до Вісли, почали спішно покидати межі міста, розпочалась гарячкова евакуація німецьких владних структур із Варшави. Вермахтом також була здійснена часткова евакуація з Варшави складів (Дейвіс, 2008: 800). Непослідовність і квапливість дій німців у польській столиці була обумовлена стрімким наступом РА i невизначеністю німецького командування, яке не одразу опанувало ситуацію після спроби антигітлерівського перевороту і замаху на А. Гітлера 20 липня 1944 р.

Населення міста бачило поспішну евакуацію німців з Варшави і чуло гуркіт канонади з боку лівого берега Вісли. Сприйнявши евакуаційні заходи німців як завершення німецької окупації в столиці, містяни бойкотували німецькі накази виходу 100 тис. осіб до робіт з будови укріплень довкола міста. Відсутність німецьких репресій за непослух було трактовано містянами як вияв слабкості гітлерівців і підтвердження очікувань. (Мельник) Здавалось, що найближчим часом німці залишать Варшаву.

Таким чином, аналіз воєнних передумов Варшавського повстання, 3 врахуванням задіяних військових з'єднань РА і очевидної переваги у силах i засобах після розгрому групи армій «Центр», наштовхує на цілком очевидний висновок, що станом на початок серпня РА була цілком здатна у короткостроковій перспективі звільнити Варшаву від німецьких військ. Звичайно, вразі продовження бойових дій на початку серпня, спрямованих на виконання плану зі звільнення польської столиці, чого, за виключенням розширення і укріплення плацдармів південніше Варшави, не відбулося. На варшавському напрямку воєнна обстановка на початку серпня почала характеризуватися стабілізацією фронту, відбиттям нечисленних, хоч в 
окремих ділянках і доволі масованих, контрударів німецьких військ, підтягуванням підрозділів забезпечення тощо. Артилерія РА в ніч на 1 серпня замовкла, авіація також припинила діяльність на цьому відрізку. 3 ночі «на лінії фронту і у повітрі» за свідченнями високопоставлених очевидців АК і емігрантського уряду запанувала страшна, дивна i не пояснювана нічим тиша (Pużak, 1977: 85).

Пояснює призупинення наступу радянських військ на початку серпня Директива Ставки Верховного Головнокомандування заступнику Верховного Головнокомандуючого, командуючим військами 1-м і 2-м Білоруським, 1-м Українським фронтів від 29 липня про покладення «на заступника Верховного Головнокомандуючого Маршала Радянського Союзу Жукова не лише координування, але й керівництва операціями, що проводяться військами 1-го Українського фронту, 1-го Білоруського фронту і 2-го Білоруського фронту» (Русский архив, 1994: 202). Результат Директиви не забарився і на Донесення командуючого 2-ю танковою армією командуючому військами 1-го Білоруського фронту про наявність Варшавського укріпленого району та рішення наступати на місто Прагу передмістя Варшави від 30 липня 1944 р. К. Рокосовським, який цього ж дня наказував 4-м арміям форсувати Віслу (Русский архив, 1994: 202-203), було накладено резолюцію від 30.07.1944 р., що вимагала від командарма 2-ї танкової армії «діяти по обстановці штурма укріпрайонів й довготривалих оборонних споруд уникати...» (Русский архив, 1994: 204). Хоча 2-а танкова армія в цей період, зокрема, станом на 4-е серпня, вже після боїв 1-3 серпня, без врахування 50 танків, 24 гармат і 61 міномета 3го танкового корпусу, лише танків мала 344 одиниці (Русский архив, 1994: 213-214).

За умов призупинення радянського наступу на варшавському напрямку стратегічна ситуація на початку серпня зазнала змін. Німецьке командування оговталося після стрімких наступальних дій РА і Гітлер 
вирішив утримати польську столицю як стратегічно важливий укріплений вузол запланованого фронту по лінії річок Вісла й Нарєв, за всяку ціну. Скориставшись раптовим призупиненням радянського наступу, німецьке командування зосередило у Варшаві авіацію, артилерію, танки й живу силу. Населення столиці стало свідком прибуття свіжих німецьких частин. Німецька оборона зміцнила позиції на підступах до міста. Таким чином, замість оперативного простору між радянсько-німецьким фронтом, на який розраховували розробники плану повстання, було повне оточення повсталих у польській столиці посиленим наприкінці липня - на початку серпня німецьким угрупуванням.

Незважаючи на настільки складну ситуацію, варшавське повстання, після поширення серед підрозділів АК наказу головнокомандувача генерала Т. Коморовського (позивний «Бур») про його початок 1 серпня 1944 р. о 17.00 (в годину «W»), було вже невідворотнім. Відмінити наказ у зв'язку зі зміною ситуації і зупиненням радянського наступу в ніч з 31 липня на 1 серпня було неможливо через особливість підпільної організації та структури АК.

Слід окремо зазначити, що рішення про початок повстання, 3 сумнівами і ваганнями, під впливом просування радянських військ в бік Варшави та евакуації зі столиці німців (Русский архив, 1994: 236), було ухвалене 31 липня після 17 год. і впродовж кількох годин наказ про початок повстання на наступний день було доведено до аківців Варшави (Скорич, 2016: 156). Зважаючи на очевидну присутність радянських розвідників у Варшаві можна впевнено говорити, що радянське керівництво знало про попередні плани керівництва АК щодо повстання у столиці, і що ще до настання пізньої ночі було поінформовано щодо відповідного наказу про початок повстання. Можливо й до 21-ї години 31 серпня, до зустрічі Наркома Закордонних справ В. Молотова з прем'єрміністром уряду в еміграції С. Миколайчиком, який, повідомивши 
радянському Наркому про те, що «...Польський уряд обмірковував план генерального повстання у Варшаві й хотів би просити Радянський уряд про бомбардування аеродромів біля Варшави» (Русский архив, 1994: 205-206), свідомо чи несвідомо, але підтвердив очевидно наявну у Москви інформацію.

Безсумнівно, що в Кремлі було добре відомо про операцію АК під кодовою назвою «Буря» та повстання у Варшаві як одну з ії складових, що передбачала повстання на довоєнних польських територіях в проміжок між відступом німецьких та приходом радянських військ і мала стратегічний розрахунок на опанування населених пунктів й встановлення місцевої та політичної влади АК та лондонського еміграційного уряду С. Миколайчика як головної передумови утворення незалежної польської держави. Виходячи 3 цього, очевидним і невипадковим є збіг в часі призупинення наступу радянських військ, з врахуванням необхідного часу на ухвалення рішення на рівні Ставки і поінформування уповноважених осіб 3 радянського військового керівництва, 3 ухваленим головнокомандувачем АК генералом Т. Коморовським рішенням про початок повстання у Варшаві і поширенням наказу серед підрозділів АК.

Додатково підтверджує тезу про політичні мотиви ухвалених рішень Кремля щодо долі Варшавського повстання 1944 р. відмова у допомозі повсталим у польській столиці. Впродовж усього періоду Варшавського повстання 1944 р. керівництво АК у Варшаві неодноразово зверталися за допомогою у питанні постачання зброї, боєприпасів, амуніції, провізії тощо як до польського уряду в Лондоні, так i до радянського командування. Так, 8 серпня командувач округом Варшава АК А. Хрусцель («Нурт») звертався до К. Рокосовського, за день до цього радянський офіцер - колишній військовополонений капітан Калугін також повідомляв радянському командуванню про потреби АК і місця бомбардувань 3 повітря у Варшаві, де зосереджено німецькі війська 
(Русский архив, 1994: 469-470). Уповноважені особи британського уряду, британської військової місії в СРСР, посольства Великої Британії декілька разів передавали в Кремль інформацію про потреби повсталих та їх прохання (Русский архив, 1994: 210-211, 220-223, 227-228, 231, 246-247). С. Миколайчик особисто звертався до Й. Сталіна 3 серпня під час прийому про допомогу повсталим «ззовні» і про «постачання зброї на пункти, які вони контролюють» (Sprawa polska, 1965: 553-559). Окрім цього, посольство США зверталося з проханням дозволити американським ВПС використовувати радянські аеродроми для посадки під час виконання операцій по допомозі повсталим (Русский архив, 1994: 228-229). Проте Кремль і радянське командування, як видно з документів, на початковому етапі повстання ігнорувало такі звернення, прикриваючись ідеологічними кліше про авантюру у Варшаві (Русский архив, 1994: 231-232, 237, 247 249).

Прикметно, що лише на етапі очевидної кризи повстання і початку ліквідації його осередків поблизу Вісли, тобто через понад п'ять 3 половиною тижнів, радянські війська відновили бойові дії на Варшавському напрямку і спільно 3 підконтрольною 1-ю армією ВП під командуванням генерала 3. Берлінга розпочали наступ на варшавське передмістя Прагу. Цілком очевидним і логічним з точки зору політичних міркувань Кремля про комуністичне майбутнє Польщі є зв'язок між суперечливими заявами Й. Сталіна про його згоду надавати допомогу повстанцям і одночасною відмовою радянського керівництва надати радянські аеродроми для посадки літаків західних союзників, що здійснювали польоти на Варшаву, та ігноруванням повстання у Варшаві й ненаданням власне радянської допомоги повсталим, зміною цієї позиції 9 вересня 1944 р. і рішенням радянської сторони про надання матеріальної допомоги повстанцям, що збігається з датою початку наступу радянських і польських військ на Прагу. Ці суперечливі і непослідовні на перший 
погляд події підпорядковуються важливій для Кремля передумові звільнення від німецьких військ польської столиці - усунення політичної конкуренції шляхом знищення АК та ії прибічників. Можна погодитися 3 польською дослідницею Г. Дильонговою, що «Сталін використав свою вирішальну перевагу для знищення керівників АК, повстанців і самого міста, що мало великі традиції конспірації та боротьби за незалежність... Він це робив руками німців, унеможлививши допомогу союзників повсталій столиці та стримавши наступ Червоної армії на всьому польському фронті від Карпат до Варшави і далі на північ» (Дильонгова, 2007: 154).

Активізація радянських військ протягом 10-14 вересня силами 1-го Білоруського фронту під командуванням маршала К. Рокосовського припала на період вже невідворотної поразки Варшавського повстання, буржуазно-націоналістичного повстання 3 точки зору радянської влади. (Ісаєв) Згідно плану радянського командування, реалізованого силами 47-ї і 70-ї армій та 1-ї армії ВП під командуванням генерала 3. Берлінга, перекинутої з магнушевського плацдарма, в результаті концентричного наступу було ліквідовано німецький плацдарм і опановано варшавське передмістя Прага (Назаревич, 1989: 165-168).

Ідеологеми на кшталт таких, що звільнення передмістя Прага в цей період розглядалося радянським командуванням лише як операція місцевого значення, є очевидними. 3 точки зору військової науки, 3 врахуванням стратегічних завдань радянських військ на цей період, реалізація операції не лише дозволяла створити додатковий плацдарм під Варшавою з можливістю більш дієвого залучення артилерії у перспективі боїв за звільнення польської столиці, але й мала далекоглядні політичні наслідки. Саме політичними факторами були продиктовані рішення про направлення підрозділів ВП спочатку на магнушевський плацдарм, а згодом залучення його ж на опанування Праги на лівобережжі Вісли і до 
захоплення плацдарму на варшавському правому березі Вісли в районі Чернякува на противагу майже розбитій в цей час АК у Варшаві (Русский архив, 1994: 216, 218-219, 221-222, 246, 249-251).

Але форсування Вісли ВП 16 вересня було вже несвоєчасним, надто запізнілим і невдалим через локалізацію німцями осередків повстання i витіснення повсталих з територій поблизу західного берега Вісли та значне укріплення німецької оборони на цьому напрямку. Додатковими факторами, що призвели до зриву операції 3 форсування Вісли та опанування польської столиці, була слабка реалізація плану операції, відсутність досвіду і недостатня кількість задіяних сил та засобів ВП у звільненні Варшави, відсутність належної підтримки підрозділами радянських військ, що були задіяні головним чином на південному та північному плацдармах. Загалом операція з форсування Вісли за участю підрозділів ВП виглядає радше як демонстративний політичний маневр Кремля. За оцінками самих представників керівного складу РА 4-5 дивізій могли вирішити кращу долю повстання і польської столиці. Але підрозділи ВП, що не пробилися до повсталих, без посилення радянськими військами, важким озброєнням, за фактичної бездіяльності радянської авіації та артилерії, 22 вересня, ще до падіння Чернякува, Мокотува та Жолібожа, було переправлено на східний берег Вісли (Русский архив, 1994: 271-275, 290-293). Так долю варшавського повстання, як і власне Варшави, було вирішено остаточно.

Висновки. Отже, ключовими і визначальними щодо перебігу подій воєнно-політичними передумовами Варшавського повстання було потрапляння Польщі влітку 1944 р. в оперативну сферу дій РА, сферу політичного впливу і відповідальності Радянського Союзу внаслідок розгрому групи армій «Центр» і виходу до території Польщі по р. Вісла РА влітку 1944 р. та утворення 21 липня 1944 р. у Москві ПКНВ на противагу визнаному західними союзниками й діючому з 1939 р. уряду Польщі у 
вигнанні, що не визнавався Кремлем після розірвання відносини 25 квітня 1943 р. за ініціативою саме радянської сторони.

Аналіз воєнних передумов Варшавського повстання 1944 р., врахування задіяних військових з'єднань РА та їх очевидної переваги у силах і засобах після розгрому групи армій «Центр», наявність плацдармів на західному березі Вісли південніше польської столиці, ситуації всередині німецького вищого військового командування після антигітлерівського перевороту і замаху на А. Гітлера 20 липня 1944 р. та становища німецьких збройних сил на варшавському напрямку до прибуття підкріплення впродовж кінця липня - початку серпня, наявних у Варшаві та її передмісті кількадесят тисяч навчених, вмотивованих і озброєних бійців польського Руху опору - щонайперше АК, формують висновок, що станом на початок серпня РА була цілком здатна у короткостроковій перспективі звільнити Варшаву від німецьких військ.

Проте в ніч на 1 серпня наступ радянських військ на варшавському напрямку було призупинено до 9 вересня, що виявилося у припиненні роботи артилерії та авіації, зупиненні наказом командуючого військами 1го Білоруського фронту К. Рокосовського просування частин 2-ї танкової армії у бік варшавського передмістя Прага, переході радянських військ на варшавському напрямку до довготривалої оборони за умов їх суттєвої переваги над німецькими, особливо в авіації та артилерії.

Зважаючи на вищезазначені воєнно-політичні передумови, ми вважаємо очевидними політичні мотиви зупинення радянського наступу на початку серпня 1944 р. на Варшавському напрямку. Додатково на користь висновку про політичні причини призупинення наступу свідчить Директива Ставки Верховного Головнокомандування від 29 липня про покладання командування трьома фронтами на Г. Жукова, спрямування наприкінці липня 1944 р. підрозділів 1-ї армії ВП під командуванням генерала 3. Берлінга на ділянку між пулавським i магнушевським 
плацдармами замість варшавського передмістя Прага, нічим не пояснюваний збіг в часі щодо ухвалення головнокомандувачем АК рішення про початок повстання у Варшаві i призупинення наступу радянських військ, з врахуванням необхідного часу на ухвалення рішення в Кремлі та поінформування про нього уповноважених осіб з радянського військового керівництва, найімовірніше, Маршала Г. Жукова та командуючого військами 1-го Білоруського фронту К. Рокосовського.

Внаслідок відсутності будь-якої допомоги з боку радянських військ до другої декади вересня, що збігається з початком наступу радянських й підконтрольних польських військ на Прагу 9 вересня 1944 р. і припадає на період вже невідворотної поразки повстання, та неможливості дієвої допомоги з боку союзницьких сил через відмову керівництва СРСР надати радянські аеродроми для посадки літаків західних союзників, що здійснювали польоти на Варшаву, повстання, через значну перевагу противника, було приречене на поразку. Форсування Вісли ВП 16 вересня, запізніле та невдале, зіграло роль чергового демонстративного політичного маневру Кремля.

Варшавське повстання 1944 р., що тривало 63 дні, завершилося поразкою підписанням капітуляції увечері 2 жовтня. Задуми Кремля про комуністичне майбутне Польщі та усунення політичної конкуренції шляхом знищення АК і іï численних прибічників, знищення польської столиці з їі духом свободи і великими традиціями конспірації й боротьби за незалежність руками німців стали ключовою причиною поразки повстання. Трагічна поразка Варшавського повстання 1944 р. стала наслідком та проявом національної політики радянського комуністичного режиму щодо польського народу як одного 3 багатьох, що прагнули свободи і незалежності. 
Алтунин, 1984 - Алтунин А.Т. Звезды над Вислой. М., 1984. 317 с.

Дейвіс, 2008 - Дейвіс Н. Боже ігрище: історія Польщі. К., 2008. 1080 c.

Дильонгова, 2007 - Дильонгова Г. Історія Польщі 1795-1990. К., 2007. $239 \mathrm{c}$.

Ісаєв - Ісаєв I. Чому Варшавське повстання зазнало поразки? [Електронний ресурс]. Режим доступу: http://www.polradio.pl/5/198/Artykul/215541

Ісаюк - Ісаюк О. Варшавське повстання. Розповідь про одну подію. [Електронний ресурс]. Режим доступу: http://incognita.day.kiev.ua/varshavske-povstannya.html

История, 1978 - История Второй мировой войны. 1939-1945. В двенадцати томах. М., 1978. Т. 9. 575 с.

Лук'янюк - Лук'янюк В. Поразка Варшавського повстання. [Електронний ресурс]. Режим доступу: http://www.jnsm.com.ua/cgi$\mathrm{bin} / \mathrm{m} / \mathrm{tm} . \mathrm{pl}$ ?Month $=10 \&$ Day $=02 \& \mathrm{a}=\mathrm{P}$

Мельник - Мельник I. Варшавське повстання 1944 року. [Електронний ресурс]. Режим доступу: http://zbruc.eu/node/25161

Мельтюхов, 2004 - Мельтюхов М.И. Операция «Багратион» и Варшавское восстание 1944 года // Вопросы истории. 2004. № 11. С. 44-56.

Назаревич, 1989 - Назаревич Р. Варшавское восстание 1944 год: политические аспекты. М., 1989. 232 с.

Польша, 2012 - Польша в XX веке. Очерки политической истории. Редакционная коллегия: Г.Ф. Матвеев, А.Ф. Носкова (отв. ред.), Л. С. Лыкошина. М., 2012. 952 с.

Русский архив, 1944 - Русский архив: Великая Отечественная. Том 14 (3-1): СССР и Польша: 1941-1945. К истории военного союза: Документы и материалы. М., 1994. 492 с. 
Скорич, 2016 - Скорич Л. В. Аналіз подій Варшавського повстання 1944 року з позицій сучасності // Військово-науковий вісник. 2016. Вип. 25. C. 154-161.

Штеменко, 1968 - Штеменко С.М. Генеральный штаб в годы войны. M., $1968.415 \mathrm{c}$.

Gdański, 2005 - Gdański J.W. Zapomniani żołnierze Hitlera. Poznań, 2005. $264 \mathrm{~s}$.

Wojna po wojnie, 2012 - Wojna po wojnie: antysowieckie podziemie w Europie Śródkowo-Wschodniej w latach 1944-1953 / Grzegorz Motyka, Rafał Wnuk, Tomasz Stryjek, Adam F. Baran. Gdańsk; Warszawa, 2012. 666 s.

Pużak, 1977 - Pużak K. Wspomneinia 1939-1945. Zeszyty Historyczne. Paris, 1977. Z. 41. S. 3-196.

Sprawa polska, 1965 - Sprawa polska w czasie drugiej wojny swiatowej na arenie miedzynarodowej. Zbior dokumentow. Warszawa, 1965. $836 \mathrm{~s}$.

Tebinka, 2004 - Tebinka J. Sprawa polska w polityce Wielkiej Brytanii i Stanów Zjednoczonych (od Teheranu do Jałty) // Mazowieckie Studia Humanistyczne, Nr 1-2, 2004. S. 137-159.

\section{REFERENCES}

Altunin, 1984 - Altunin A.T. Zvezdy nad Visloy. [Stars over the Vistula]. M., 1984. 317 s. [in Russian].

Dejvis, 2008 - Dejvis N. Bozhe igry`shhe: istoriya Pol`shhi. [God's merriment: the history of Poland]. K., 2008. 1080 s. [in Ukrainian].

Dy```ongova, 2007 - Dy```ongova G. Istoriya Pol`shhi 1795-1990. [History of Poland 1795-1990.]. K., 2007. 239 s. [in Ukrainian].

Isayev - Isayev I. Chomu Varshavs`ke povstannya zaznalo porazky’? [Why was the Warsaw uprising defeated?]. [Elektronny`j resurs]. Rezhy`m dostupu: http://www.polradio.pl/5/198/Artykul/215541 [in Ukrainian]. 
Isayuk - Isayuk O. Varshavs`ke povstannya. Rozpovid` pro odnu podiyu. [Warsaw uprising. Story about one event]. [Elektronny`j resurs]. Rezhy`m dostupu: http://incognita.day.kiev.ua/varshavske-povstannya.html [in Ukrainian].

Istoriya, 1978 - Istoriya Vtoroy mirovoy voyny. 1939-1945. V dvenadtsati tomakh. [History of the Second World War. 1939-1945. In twelve volumes]. M., 1978. T. 9.575 s. [in Russian].

Luk'yanyuk - Luk'yanyuk V. Porazka Varshavs`kogo povstannya. [Defeat of the Warsaw Uprising]. [Elektronny`j resurs]. Rezhy'm dostupu: http://www.jnsm.com.ua/cgi-bin/m/tm.pl?Month=10\&Day=02\&a=P [in Ukrainian].

Mel`ny`k - Mel`ny`k I. Varshavs`ke povstannya 1944 roku. [Warsaw Uprising of 1944]. [Elektronny`j resurs]. Rezhy`m dostupu: http://zbruc.eu/node/25161) [in Ukrainian].

Meltyukhov, 2004 - Meltyukhov M.I. Operatsiya «Bagration» i Varshavskoe vosstaniye 1944 goda // Voprosy istorii. [Operation Bagration and the Warsaw Uprising of 1944] // Issues of history] 2004. № 11. S. 44-56. [in Russian].

Nazarevich, 1989 - Nazarevich R. Varshavskoe vosstaniye 1944 god: politicheskiye aspekty. [The Warsaw Uprising of 1944: Political Aspects] M., 1989. 232 s. [in Russian].

Polsha, 2012 - Polsha v XX veke. Ocherki politicheskoy istorii. [Poland in the XX century. Essays on political history]. M.. 2012. 952 s. [in Russian].

Russkiy arkhiv, 1994 - Russkiy arkhiv: Velikaya Otechestvennaya. Tom 14 (3-1): SSSR i Polsha: 1941-1945. K istorii voennogo soyuza: Dokumenty i materialy. [Russian archive: The Great Patriotic War. Volume 14 (3-1): The USSR and Poland: 1941-1945. To the history of the military alliance: Documents and materials]. M., 1994. 492 s. [in Russian]. 
Skory`ch, 2016 - Skory`ch L.V. Analiz podij Varshavs`kogo povstannya 1944 roku z pozy'cij suchasnosti [Analysis of the events of the Warsaw Uprising of 1944 from the standpoint of modernity] // Vijs`kovo-naukovy`j visny`k. 2016. Vy`p. 25. S. 154-161. [in Ukrainian].

Shtemenko, 1968 - Shtemenko S.M. Generalnyy shtab v gody voyny [General Staff during the war] M., 1968. 415 s. [in Russian].

Gdański, 2005 - Gdański J.W. Zapomniani żołnierze Hitlera. Poznań, 2005. 264 s. [in Polish].

Wojna, 2012 - Wojna po wojnie: antysowieckie podziemie w Europie Śródkowo-Wschodniej w latach 1944-1953 / Grzegorz Motyka, Rafał Wnuk, Tomasz Stryjek, Adam F. Baran. Gdańsk; Warszawa, 2012. 666 s. [in Polish].

Pużak, 1977 - Pużak K. Wspomneinia 1939-1945. Zeszyty Historyczne. Paris, 1977. Z. 41. S. 3-196. [in Polish].

Sprawa polska, 1965 - Sprawa polska w czasie drugiej wojny swiatowej na arenie miedzynarodowej. Zbior dokumentow. Warszawa, 1965. 836 s. [in Polish].

Tebinka, 2004 - Tebinka J. Sprawa polska w polityce Wielkiej Brytanii i Stanów Zjednoczonych (od Teheranu do Jałty) // Mazowieckie Studia Humanistyczne. Nr 1-2. 2004. S. 137-159. [in Polish]. 